\title{
Agricultural By-Product Proteins: Emerging Source for Packaging Applications
}

\author{
T. G. G. Uthpala ${ }^{1, *}$, S. B. Navaratne ${ }^{1}$, Amila Thibbotuwawa ${ }^{2}$, M. Jayasinghe ${ }^{1}$, R. S. Wanigasinghe ${ }^{3}$ \\ ${ }^{1}$ Department of Food Science and Technology, Faculty of Applied Sciences, University of Sri Jayewardenepura, Sri Lanka. \\ ${ }^{2}$ Department of Transport and Logistics Management, Faculty of Engineering, University of Moratuwa, Sri Lanka. \\ ${ }^{3}$ Department of Biotechnology, Faculty of Agriculture and Plantation Management, Wayamba University of Sri Lanka, Sri Lanka.
}

How to cite this paper: T. G. G. Uthpala, S. B. Navaratne, Amila Thibbotuwawa, M. Jayasinghe, R. S. Wanigasinghe. (2021) Agricultural By-Product Proteins: Emerging Source for Packaging Applications. International Journal of Food Science and Agriculture, 5(3), 355-362.

DOI: $10.26855 /$ ijfsa.2021.09.003

Received: May 7, 2021

Accepted: June 2, 2021

Published: July 6, 2021

*Corresponding author: T. G. G. Uthpala, Department of Food Science and Technology, Faculty of Applied Sciences, University of Sri Jayewardenepura, Sri Lanka.

Email: gimhani@sci.sjp.ac.lk

\begin{abstract}
Regular use of petroleum-based plastic packaging films has led to environmental impact due to their total non-biodegradability. Substantially, the food industry generates waste and agricultural-based raw materials have recently been applied to produce biodegradable, renewable and safe to eat packaging materials as a viable alternative to aforesaid dire consequences. Agro packaging concept has emerged where valuable compounds from by-products such as proteins are extracted from animal or plant sources to produce biofilms. Proteins are generally superior to the qualities of other biological compounds available in agricultural by-products. Their ability to form films with better mechanical and barrier properties has been studied and researches are in the process of exploring novel technologies in developing sustainable food packaging materials that are edible and active. This review explores possible applications of animal and plant protein sources from the agricultural by-products in bio-based film production and the inherited properties of these films. Moreover, selected animal by-product proteins such as collagen, gelatin, casein, myofibrillar proteins, keratin as well as plant by-product proteins including soy protein, wheat gluten, corn-zein, canola protein are discussed in details with special reference to available redundant protein types, technologies applied to obtain films, mechanical properties, functions of films and their applications.
\end{abstract}

\section{Keywords}

Bio-Based Film, By-Product Protein, Protein Films, Agro Packaging, Sustainable Packaging

\section{Introduction}

Significance of the food packaging materials has increased over time due to the gradual increment of the global population and industrialization of food production. The concerns of packaging are to protect food from mechanical damage, water vapor, oxygen and other contaminants while improving the shelf life, merchandise, market and assure safety of the food until it delivered to consumer [1, 2, 3]. At the initial stages of food packaging, glass, metal, wood, paper and paperboard etc. were used for wrapping the food basically to prevent damages and contaminations. With the time those traditional materials were replaced by polymerized materials, majorly plastics due the additional benefits such as cost effectiveness, easiness and low cost. The eventual objective of food packaging is to cover the food items in a profitable approach that captures both needs of the producer as well as the consumer. It also accounts management of food safety and lowering environmental impact by the use of packaging over time. As a result of that, development of packaging materials lead to producing bio-films and coatings from biological materials [4] over recent decades.

Agricultural based raw materials have been utilized to develop bio degradable, edible and sustainable packaging materials [5]. Based on their raw materials, a substantial amount of waste ranging from $5 \%$ to $90 \%$ is generated in the food 
processing industry [6]. The agro packaging concept has emerged over 50 years ago and it is basically related with development of renewable products and controlling its disposal [5, 7]. Majority of protein-based materials are extracted from animal or plant sources which concerned as biodegradable. They are highly preferable than polysaccharide qualities in respect to capabilities in film forming with high mechanical properties such as tensile strength, elongation ability, thickness and thermal properties etc. [7]. Further, protein films have good barrier properties and high in nutritional value. Among agricultural products, proteins are practically used for packaging such as collagen for sausage casings and wheat gluten for encapsulation etc. rather than other bio polymers. Accordingly, both protein-based films as well as coatings are attractive alternatives for conventional petroleum-based materials. To achieve optimum quality of packaging material, barrier properties, water solubility and mechanical properties needed to be improved. Physical, chemical, and biochemical techniques are used to obtain these materials where wet and dry processes $[7,8]$ are applied as technological methods to form packaging materials.

Moreover, agricultural by product proteins can be utilized for control discharge of additives and bioactive compounds. There are several research studies have been implemented to develop films and coatings from numerous protein sources since 1950 [9, 10]. Even though, studies have been done to produce packaging films using by-product proteins such as cereals, legumes, milk, fish and meat [11, 12, 13, 14], the effectiveness of these films is not yet satisfied.

This review reveals possible implementations of animal and plant protein sources from the agricultural and food industrial by-products in bio-based film production and the inherited properties of these films. Moreover, selected by-product proteins are explored in details with special reference to available redundant protein types, technologies applied to obtain films, mechanical properties, functions of films and their applications.

\section{Agricultural by-product protein based packaging applications}

\subsection{Animal byproduct proteins}

\subsubsection{Collagen and Gelatin}

Collagen is an edible raw material attributed from fresh hides or bone [15]. Researchers have revealed that $11 \%$ of pork carcasses, $15 \%$ of beef carcasses and $16 \%$ of lamb carcasses are bone [14]. If those carcasses comprised of the meat clinging to the bone these percentages get increased. Therefore these animal sources can be used to obtain gelatin and collagen proteins. Gelatin can be obtained from hide through three main steps. The initial step is elimination of other materials except collagen out of the raw material which is succeeded by controlled hydrolysis of water insoluble collagen to form gelatin [14]. The final step is the final product recovery and dehydration process

The physical and chemical properties of extracted gelatin are highly influenced by the origin of raw materials, age of the animal, type of collagen available and the extraction technique applied for process [16]. In 2011, the global gelatin production was 348.9 kilo tons and estimated to reach 450.7 kilo tons in the year 2018. Moreover, in the past seven years, global gelatin production improved at a CAGR (compound annual growth rate) of 3.73\% [15]. Collagen is applied in the meat industry to produce coatings which are edible over extrusion [17, 18, 19]. Progressively gelatin has been operated to develop films that are transparent, water-resistant, flexible and impassable to oxygen [19, 20]. Gelatin based aqueous solution which is subjected to cooling and drying process can form these films. These films are utilized to fabricate tablets and capsules [15, 21]. The protein; gelatin has been extensively studied due to its rich filming properties and protecting ability which leads extending shelf life. Gelatin films are applied to assure safeness of frozen meats products from oxidation $[9,10]$ with addition of antioxidants to films.

\subsubsection{Casein}

Casein is found in dairy products which account 80 percent of overall milk protein content. Casein is obtained by acidifying the milk (isoelectric point 4.6) or addition of rennet to milk. The casein is then [22] being separated, washed, and dried. This casein protein is composed of three types of proteins named $\alpha, \beta$, and $\kappa$ casein. They can develop colloidal micelles in milk that are being stabilized by a calcium-phosphate bridge [15]. Attributed to good functional properties, aqueous casein and caseinate solutions can be convinced into develop edible films. As shown in Table 1, casein films are produced either casting it in thin layer followed by drying the film-forming solution or collection of skin made subsequently after heating the protein solution. Also it can be obtained by enzymatic polymerization method by using rennet [15].

Caseins diffused in liquid can develop transparent, pliable and flavorless films. Transglutaminases or peroxidases can be used as a catalyzer to build covalent cross-links which improves water resistance or letting immobilization of active enzymes [22]. Another benefit of safe to eat casein films is the ability to act as a good barrier against nonpolar molecules including Oxygen [19]. This property is due to casein provides a great quantity of polar functional groups, such as hydroxyl and amino groups toward the film matrix. This makes casein film to become active packaging and further ability to combine with other packaging materials in order to prevent food from oxidation or moisture absorption. 


\subsubsection{Myofibrillar protein}

Myofibrillar protein is made from myosin and actin proteins, which account for about $70 \%$ of total proteins in fish muscle. Myofibrillar proteins which are originated from seafood are thermally unstable than the proteins originated from terrestrial animal sources [23]. Past research studies have revealed that the film developing potential of fish myofibrillar proteins recovered from aqueous solutions. These films are insoluble in water, transparent and owe better gas barrier properties [19, 24]. Table 1 presents the properties of agricultural by-product proteins, respectable proteins, methods applied to obtain the film. The thermoplastic properties of myofibrillar proteins, emerge industrial edible film production usually by the conventional techniques (thermo-extrusion, thermos-molding) which applied to synthetic polymers. The solvent process occurred by initially casting a film-forming solution is influenced by acidity and concentration of protein $[7,19,25]$.

\subsubsection{Keratin}

The keratin is a common protein that originated in the body of mammals, birds and reptiles. Keratin supports strength to body and it is the structural component of nail, horn, wool and feathers [26]. Extensively keratin is obtained from body parts of farm animals including goat skins, sheepskins, cattle hides and buffalo hides [27]. Food industry generates million tons of keratin biomass.

Keratin obtained from less expensive chicken feather can be plasticized into films which perform better mechanical properties [28]. Researchers have developed water proof films by casting and drying alkaline dispersion of keratins [29]. The large amount of cysteine in keratin aids to build disulfide bonds which could secure the structure of proteins [11, 30]. Due to their undesirable flavor, keratin based edible coatings have limited implementations [31]. Therefore, diverse polymer combinations have recently emerged combine with keratin [26] such as keratin-chitosan [32], keratin-polypropylene [33] which are having higher film forming capabilities.

\subsection{Plant byproduct proteins}

\subsubsection{Soy protein}

Soy proteins have been applied to produce edible films through aggregating the lipoprotein film developed after boiling soya milk (e.g., yuba/tofu skin) [34, 35, 36]. Most soy proteins are globulins that solubilize in salt solutions [37, 38].

Even though protein is the major ingredient of soy protein based films, a convincing amount of polysaccharides (sucrose, raffinose, and stachyose) and lipids (globules included in the proteic network) are available which causes better mechanical properties. Also there are films that have been developed from soy protein isolates prepared in aqueous alcoholic solutions, either by obtaining the lipoproteic skin formed by boiling soya solutions [39, 40] or by casting solutions in thin layers and drying. Soy films have commonly been improved as edible coating materials to preserve foods [38]. Also biodegradable plastics have made from soy isolate and concentrate by thermos-molding technique [41].

\subsubsection{Wheat gluten}

Numerous studies [30, 42, 43, 44] refer to the film-forming properties (Table 1 and Table 2) of wheat gluten proteins. Wheat proteins range from $8 \%-15 \%$ of the dry weight of wheat kernel. From wheat endosperm $70 \%$ of the total protein is composed of gliadin and glutenin.

Wheat gluten-based films are conventionally developed by casting in a thin layer and then drying of aqueous alcoholic solutions with a disruptive agent (sulfite) [45]. Films made from wheat gluten, have also been expanded by collecting the skin obtained after boiling protein solutions [11]. These films are water insoluble, and their functional attributes are comparable to those of corn-zein films. These wheat gluten films have applied in additive encapsulation, quality developments in cereal products, and retention of antimicrobial or antioxidant potential on food surfaces [25].

Nevertheless, gas barrier properties (Table 2) of these films including their gas selectivity are applied to extend the durability of fresh and minimally processed vegetables [46]. Even though, molded and biodegradable plastics made from wheat proteins are used in food industry, due to its thermoplastic behavior and chemical modification abilities (modified hydrophobicity rate and compatibility with synthetic materials) nonfood uses are also available [46, 47].

\subsubsection{Corn-Zein protein}

Zein is a major protein present in corn which classified under prolamin proteins [48]. They are soluble in 70-80\% ethanol, comparably hydrophobic and thermoplastic. Film-forming properties of corn $\alpha$-Zein have been broadly researched [47, 48, 49, 50].

The zein films taken from dried water/ethanol mixtures are water-insoluble but comparatively grease-resistant and better in quality. Zein based films and coatings are applied in perishable food preservation, enrichment of vitamins and discharging bioactive active compounds. Aqueous dispersions of zein are commercially marketed as films. Corn-zein coated tomatoes before the maturity stage had shown delaying in ripening [49]. Starch and zein combinations have researched for producing biodegradable plastics [41, 51]. Injection-molded plastics are moisture sensitive, while 
cross-linked materials show less moisture absorption and better mechanical properties.

\subsubsection{Canola protein}

Canola is a healthiest vegetable oil and a potential source of producing a variety of eco-friendly products including biodiesel and bioplastics [52]. Canola seeds naturally composed with $40 \%$ oil [53]. Canola meal consists of glucosinolates, phenolics, phytates, and significantly high fiber amount which make it problematic for food utilize [52]. Canola seeds are commonly crushed or ground to assist the separation and defatting process. Defatted meal is dehydrated at room temperature [44] or dried under vacuum oven at $40^{\circ} \mathrm{C}$. Then dried and defatted meal is grounded and passed through 40-mesh or 60-mesh [52] and screened in order to assure thorough interaction of the meal with chemicals during the protein extraction process. Also preparation of defatted canola meals can be achieved by using hexane as a solvent to make a slurry with grounded canola seeds using an orbital mill [44, 52].

The common procedure used in the preparation of canola protein is alkaline extraction (sodium hydroxide solution) along with precipitation with dilute acid [54]. This procedure may differ according to variations in $\mathrm{pH}$ of extraction, $\mathrm{NaOH}$ concentration, settings in centrifugation and filtration and $\mathrm{pH}$ of the protein precipitation. Commonly, the alkaline solution is initially added to the defatted canola meal and stirred for a selected time duration to dissolve protein [54]. Then, this mixture is centrifuged and the $\mathrm{pH}$ of supernatant is adjusted by dilute acid to precipitate the proteins. Finally, the precipitated protein is obtained through centrifugation and further, it can be preserved by freeze-drying.

Table 1. Source, types, film forming methods and properties of selected agricultural and food industrial by-product proteins

\begin{tabular}{|c|c|c|c|c|}
\hline $\begin{array}{l}\text { Source of by } \\
\text { product }\end{array}$ & Protein & Method to obtain films & $\begin{array}{l}\text { Properties/ } \\
\text { Potential bioactivity }\end{array}$ & References \\
\hline Milk casein & $\begin{array}{c}\alpha \mathrm{S} 1, \alpha \mathrm{S} 2, \beta, \kappa, \mathrm{g} \\
\text { Casein }\end{array}$ & $\begin{array}{l}\text { Casting in thin layer and drying of a } \\
\text { film-forming solution. } \\
\text { Collect skin formed after boiling } \\
\text { protein solution. } \\
\text { Enzymatic polymerization. }\end{array}$ & $\begin{array}{c}\text { Transparent, Flexible, } \\
\text { Tasteless, } \\
\text { Water-resistant, } \\
\text { Antioxidant }\end{array}$ & {$[22,19,54]$} \\
\hline $\begin{array}{l}\text { Myofibrillar pro- } \\
\text { teins }\end{array}$ & $\begin{array}{l}\text { Myosin } \\
\text { Actin }\end{array}$ & $\begin{array}{l}\text { Casting in thin layer and drying of a } \\
\text { film-forming solution. }\end{array}$ & $\begin{array}{l}\text { Thermoplastic, Gas } \\
\text { barrier abilities, Wa- } \\
\text { ter-insoluble }\end{array}$ & {$[19,56]$} \\
\hline $\begin{array}{l}\text { Seafood shrimp } \\
\text { shell }\end{array}$ & Cryotin & Enzymatic polymerization. & Anti-cancer & {$[56,57,19]$} \\
\hline Soy protein & $\begin{array}{l}\beta \text {-Conglycinin } \\
\text { Glycinin }\end{array}$ & $\begin{array}{l}\text { Casting in thin layer and drying of a } \\
\text { film-forming solution. } \\
\text { Collecting lipoproteic skin formed } \\
\text { after boiling soya milk } \\
\text { Enzymatic polymerization }\end{array}$ & Antioxidant & {$[58,60]$} \\
\hline Wheat Gluten & Gliadin,Glutenin & $\begin{array}{l}\text { Casting in thin layer and drying of a } \\
\text { film-forming solution }\end{array}$ & $\begin{array}{l}\text { Antioxidant } \\
\text { Antimicrobial }\end{array}$ & {$[19,46]$} \\
\hline Corn Zein & $\alpha$-Zein, Prolamin & $\begin{array}{l}\text { Casting in thin layer and drying of a } \\
\text { film-forming solution, Resin }\end{array}$ & $\begin{array}{c}\text { Antioxidant } \\
\text { Thermoplastic, water } \\
\text { resistant }\end{array}$ & {$[56,19]$} \\
\hline Canola oil & Canola protein & $\begin{array}{l}\text { Alkaline extraction } \\
\text { And dry method }\end{array}$ & $\begin{array}{l}\text { Antioxidant } \\
\text { Antimicrobial }\end{array}$ & {$[56,19,58]$} \\
\hline $\begin{array}{l}\text { Meat hides and } \\
\text { bones }\end{array}$ & Gelatin & $\begin{array}{l}\text { Casting in thin layer and drying of a } \\
\text { film-forming solution }\end{array}$ & $\begin{array}{c}\text { Water-resistant, } \\
\text { Transparent, Flexible, } \\
\text { Impermeable to oxy- } \\
\text { gen }\end{array}$ & {$[56,7]$} \\
\hline Meat & Collagen & Thermoplastic extrusion & Antioxidant & {$[17,19]$} \\
\hline Poultry & Keratin & $\begin{array}{l}\text { Casting and drying alkaline dis- } \\
\text { persion }\end{array}$ & $\begin{array}{l}\text { Water insoluble films, } \\
\text { unpleasant taste }\end{array}$ & {$[30]$} \\
\hline
\end{tabular}




\section{Properties and production process of protein based agro-packaging materials}

The comprehensive properties of protein-based agro-packaging materials and its three-dimensional networks are highly influenced by the interactions between polymers. The solubility of these films in aqueous solution differs based on qualities and quantities of intermolecular interactions apparent in the protein network [59]. Protein-based films are comprised of insignificant moisture levels and differently ordered macromolecular continuous networks. The ability of intermolecular bond formation relies on the shape (chain length/diameter ratio) of the protein and fabrication conditions [60]. The proteins with heavy molecular weight proteins such as glutenin and fibrous proteins like collagen have better potential of generating films with preferable mechanical properties [7, 19, 61, 62]. Nonetheless, globular or pseudo-globular proteins like gliadin, glycinin, and casein primarily required to be unfolded before network formation. Basically the macromolecular protein network formation occurs in three steps. The first step is the cleavage of poor energy owing intermolecular bonds that stabilize polymers in the natural state. Second step is the adjustment and orientation (shaping) of polymer chains. The final step is the initiation of three-dimensional network which stabilized by original interactions and the second step. Also, two technological processes that are implemented to produce protein-based materials termed as wet process and dry process [19].

The wet process has broadly studied over the past years. By implementing the wet process, protein-based materials are formed out of a protein solution or dispersion. This process requires to make a thin layer of protein solution which carried out under controlled laboratory conditions. Therefore, it is generally termed as a casting or continuous spreading method (Figure 1).

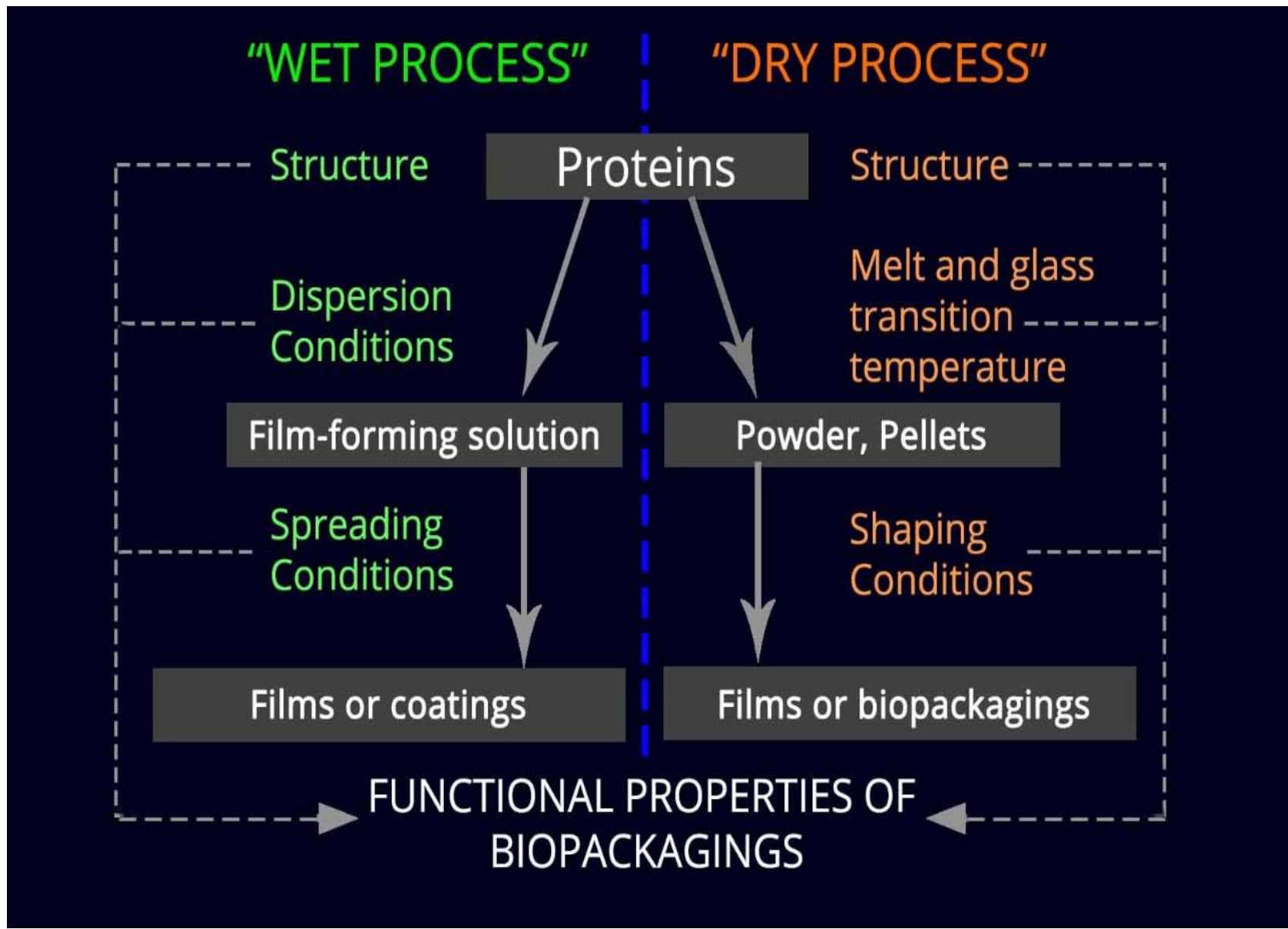

Figure 1. Schematic diagram of technologies applied to form protein-based agro-packaging materials [19].

The dry process is applied to the protein extracts with lower moisture content. Especially, it is implemented after analyzing potential thermoplastic quality which is similar to the thermoplastic property of starch-based materials [25, 19, 62]. Thermoplastic properties of proteins are explained with the glass transition theory, which defines textural changes within the thermoplastic polymer processing. The right side of Figure 1 depicts the dry process which leads to obtaining powder or pellets at a particular temperature based on the thermoplastic properties of the protein. Moreover, films could be obtained by applying proper shaping conditions. 
Table 2. Summary table of the strength, elongation, permeability and other properties of agricultural and food industrial by-product protein films

\begin{tabular}{|c|c|c|c|c|c|c|c|c|}
\hline \multirow[t]{2}{*}{ Film } & \multirow{2}{*}{$\begin{array}{c}\text { Tensile } \\
\text { strength } \\
\text { (MPa); } \\
\text { Temp. }\end{array}$} & \multirow[t]{2}{*}{$\begin{array}{l}\text { Elongation\%; } \\
\text { Temp. }\end{array}$} & \multirow[t]{2}{*}{$\begin{array}{l}\text { Thickness } \\
\text { (mm) }\end{array}$} & \multirow[t]{2}{*}{$\begin{array}{l}\text { Temp. } \\
\left({ }^{0} \mathrm{C}\right)\end{array}$} & \multirow[t]{2}{*}{$\begin{array}{l}\text { Water vapor permeability (10-12 } \\
\left.\mathrm{mol} \cdot \mathrm{m} \cdot \mathrm{m}^{-2} \cdot \mathrm{sec}^{-1} \cdot \mathrm{Pa}^{-1}\right) ; \text { Temp. }\left({ }^{0} \mathrm{C}\right)\end{array}$} & \multicolumn{2}{|c|}{$\begin{array}{c}\text { Permeability of gases } \\
\left(10^{-18} \mathrm{~mol} \cdot \mathrm{m} \cdot \mathrm{m}^{-2} \cdot \mathrm{sec}^{-1} \cdot \mathrm{Pa}^{-1}\right)\end{array}$} & \multirow[t]{2}{*}{ References } \\
\hline & & & & & & Oxygen & Carbon dioxide & \\
\hline Soy protein & 1.9 & 35.6 & 0.088 & 25 & - & 2 & - & {$[30,19]$} \\
\hline Wheat gluten & 0.9 & 26.0 & 0.088 & 25 & $3.91-5.08$ at $30^{\circ} \mathrm{C}$ & 1,290 & 36,700 & {$[30,46]$} \\
\hline Corn zein & 0.4 & - & 0.081 & 26 & 6.45 at $21^{\circ} \mathrm{C}$ & 35 & 216 & {$[30]$} \\
\hline Whey protein & 13.9 & 30.8 & - & 23 & - & - & - & [30] \\
\hline $\begin{array}{l}\text { Fish myofi- } \\
\text { brillar pro- } \\
\text { teins }\end{array}$ & 17.1 & 22.7 & 0.034 & 25 & 3.91 & 873 & 11,100 & [30] \\
\hline
\end{tabular}

\section{Future research directions and conclusions}

Expand use of petroleum based plastic packaging films has developed environmental impact owing to their total non-biodegradability. Regular consumption of plastics in multiple forms has to be diminished and may even be continuously eliminated to conserve ecology. Accordingly, shifting towards eco-friendly packaging films and processes, ensures compatibility with the nature. Aforesaid advancement also drives to conserve natural resource with reinforcing on a pollution-free environment.

The concept of agro packaging has emerged since 1950. Thus, by-product proteins from agricultural and food industrial applications are extracted from different animal or plant sources to produce biofilms. They are generally superior to the qualities of other biological compounds available in agricultural by-products. Whereas it is impossible to replace overall synthetic plastics and maybe even worthless, our attention and efforts are required in the future to utilize eco-friendly protein-based packaging materials in the food industry. Collagen, gelatin, casein, myofibrillar proteins and keratin are currently obtained from animal sources as valuable by product proteins and plant by-product protein include wheat gluten, corn-zein, soy protein, canola protein are leading economical applications of agricultural and food industrial by product management.

The convenience of utilizing proteins as agro-polymers for packaging, coating and film fabrication recommends many food industrial applications. Exceedingly, functional attributes of these agro polymers such as mechanical properties, barrier properties and optical property etc. could be utilized for packaging applications. Packaging materials could be developed from these proteins using conventional shaping techniques, such as thermoplastic processing technologies (extrusion, thermos molding) and solvent processes. Even though these processes are expensive, bio packaging meets the future gap in eco-friendly food packaging, especially for value-added products in a sustainable manner. Besides, these packaging sources also create an attractive path to waste management.

\section{Conflict of Interests}

The authors declare that they have no conflict of interests.

\section{Funding}

The authors received no financial support for the research or publication of this article.

\section{References}

[1] Zink, J., Wyrobnik, T., Prinz, T., Schmid. M. (2016). Physical Chemical and Biochemical Modifications of Protein-Based Films and Coatings : An Extensive Review, 3-45.

[2] Bugusu, K. M. (2007). Food Packaging—Roles, Materials, and Environmental Issues. J Food Sci., 72(3), 39-54.

[3] Raheem, D. (2012). Application of plastics and paper as food packaging materials_An overview. Emir J Food Agric., 2012, 25(3): 177-88.

[4] Ngcdjcs, G. (1994). Edible composite films of wheat gluten and lipids : water vapour permeability and other physical properties. Int J food Sci Technol., 39-50.

[5] Popa, M., Mitelut, A., Niculita, P., Geicu, M., Ghidurus, M., and Turtoi, M. (2009). Biodegradable materials for food packaging applications. Int. work. environ. relantionsh. fram. EU policy, 16-17. 
[6] García, M. C., Orellana, J. M., and Marina, M. L. (2016). Novel Applications of Protein By-products in Biomedicine. In Protein Byproducts (pp. 193-211). Academic Press.

[7] Cuq, B., Gontard, N., Cuq, J., and Guilbert, S. (1998). Packaging films based on myofibrillar proteins: Fabrication, properties and applications. Nahrung, 42: 260-263.

[8] Stéphane Guilbert, B. C. (1997). Recent innovations in edible and/or biodegradable packaging materials. Food Additives \& Contaminants.

[9] Klose, A. A., Mecchi, E. P., and Hanson, H. L. (1952).Use of antioxidants in the frozen storage of turkeys. Food Technology, 6, 308-311.

[10] Akbari, Z., Ghomashchi, T., and Moghadam, S. (2007). Improvement in food packaging industry with biobased nanocomposites. International Journal of Food Engineering, 3(4).

[11] Okamoto, S. (1978). Factors affecting protein film formation. Cereal Foods World, 23, 256-262.

[12] Torres, J. A. (1994). Edible Films and Coatings from Proteins. Protein Functionality in Food Systems, 467.

[13] Gueguen, J., Viroben, G., Noireaux, P., and Subirade, M. (1998). Influence of plasticizers and treatments on the properties of films from pea proteins. Industrial crops and products, 7(2-3), 149-157.

[14] Jayathilakan, K., Sultana, K., Radhakrishna, Bawa, S. A. (2012). Utilization of byproducts and waste materials from meat, poultry and fish processing industries. J Food Sci Techno, 278-293.

[15] Said, N. S. and Sarbon, N. M. (2019). Protein-Based Active Film as Antimicrobial Food Packaging: A Review. In Active Antimicrobial Food Packaging.

[16] Gómez-Guillén, M. C., Giménez, B., López-Caballero, M. A., and Montero, M. P. (2011). Functional and bioactive properties of collagen and gelatin from alternative sources: A review. Food Hydrocolloids, 25(8), 1813-1827.

[17] Courts, A. (1977). Uses of collagen in edible products. Pages 395-412 in: The Science and Technology of Gelatin. A. G. Ward and A. Courts, eds. Academic Press: New York.

[18] Hood, L. L. (1987). Collagen in sausage casings. Adv. Meat Res., 4: 109-129.

[19] Cuq, B., Gontard, N., Guilbert, S. (1998). Proteins as agricultural polymers for packaging production. Cereal Chemistry. 1998 Jan; 75(1): 1-9.

[20] Grouber, B. (1983). Les gélatines: propriétés, contrôles et principales applications. Labo-Pharm. Problèm, Techn., 337: 909-916.

[21] Uthpala, T. G. G., Navaratne, S. B., and Thibbotuwawa, A. (2020). Review on low-temperature heat pump drying applications in food industry: Cooling with dehumidification drying method. Journal of Food Process Engineering, 43(10), e13502.

[22] Wittaya, T. (2012). Protein-based edible films: Characteristics and improvement of properties. In Structure and function of food engineering. IntechOpen.

[23] Tahergorabi, R., Hosseini, S. V., and Jaczynski, J. (2011). Seafood proteins. In Handbook of food proteins (pp. 116-149). Woodhead Publishing.

[24] Gontard, N., Thibault, R., Cuq, B., and Guilbert, S. (1996). Influence of relative humidity and film composition on oxygen and carbon dioxide permeabilities of edible films. J. Agric Food Chem., 44: 1064-1069.

[25] Savary, C., Colonna, P., and Della Valle, G. (1993). Matériauxd'emballage à base d'amidonset de leursdérivés. Ind. Céréales 10: $17-29$.

[26] Reichl, S., Borrelli, M., and Geerling, G. (2011). Keratin films for ocular surface reconstruction. Biomaterials, 32(13), 3375-3386.

[27] Sharma, S. and Gupta, A. (2016). Sustainable management of keratin waste biomass: applications and future perspectives. Brazilian Archives of Biology and Technology, 59.

[28] Shi, W. and Dumont, M. J. (2014). Bio-based films from zein, keratin, pea, and rapeseed protein feedstocks. Journal of materials science, 49(5), 1915-1930.

[29] Dou, Y., Zhang, B., He, M., Yin, G., and Cui, Y. (2014). Preparation and physicochemical properties of dialdehyde starch crosslinked feather keratin/pva composite films. Journal of Macromolecular Science, Part A, 51(12), 1009-1015.

[30] Gennadios, A., Weller, C. L., and Testin, R. F. (1993). Modification of physical and barrier properties of edible wheat gluten-based films.

[31] Daniels, R. (1973). Edible coatings and soluble packaging (No. TP451. E3. D36 1973.)

[32] Vázquez, N., Chacón, M., Meana, Á., Menendez-Menendez, Y., Ferrero-Gutierrez, A., Cereijo-Martín, D., ... and Merayo-Lloves, J. (2015). Keratin-chitosan membranes as scaffold for tissue engineering of human cornea. Histology and histopathology, 30(7), 813-821.

[33] Bertini, F., Canetti, M., Patrucco, A., and Zoccola, M. (2013). Wool keratin-polypropylene composites: Properties and thermal degradation. Polymer Degradation and Stability, 98(5), 980-987.

[34] Burnett, R. S. (1951). Soybean protein food products. Soybeans and Soybean Products, 2, 950-952.

[35] Fukushima, D. and Van Buren, J. (1970). Mechanisms of protein insolubilization during the drying of soy milk. Role of disul- 
fide and hydrophobic bonds. Cereal chemistry.

[36] Brandenburg, A. H., Weller, C. L., and Testin, R. F. (1993). Edible films and coatings from soy protein. Journal of food Science, 58(5), 1086-1089.

[37] Kumar, R., Choudhary, V., Mishra, S., Varma, I. K., and Mattiason, B. (2002). Adhesives and plastics based on soy protein products. Industrial Crops and Products, 16(3), 155-172.

[38] Guerrero, P., Retegi, A., Gabilondo, N., and De la Caba, K. (2010). Mechanical and thermal properties of soy protein films processed by casting and compression. Journal of Food Engineering, 100(1), 145-151.

[39] Wolf, W. J. (1970). Soybean proteins. Their functional, chemical, and physical properties. Journal of Agricultural and Food Chemistry, 18(6), 969-976.

[40] Aoki, H., Taneyama, O., Orimo, N., and Kitagawa, I. (1981). Effect of lipophilization of soy protein on its emulsion stabilizing properties. Journal of Food Science, 46(4), 1192-1195.

[41] Jane, J., Lim, S., Paetau, I., Spence, K., and Wang, S. (1994). Biodegradable plastics made from agricultural biopolymers. 92-100.

[42] Gennadios, A., Weller, C. L., and Testin, R. F. (1993). Property modification of edible wheat, gluten-based films. Transactions of the ASAE, 36(2), 465-470.

[43] Cherian, G., Gennadios, A., Weller, C. L., and Chinachoti, P. (1995). Thermomechanical behavior of wheat gluten films: effect of sucrose, glycerin, and sorbitol. Biological Systems Engineering: Papers and Publications, 103.

[44] Aluko, R. E. and McIntosh, T. (2001). Polypeptide profile and functional properties of defatted meals and protein isolates of canola seeds. J Sci Food Agric., 81(4), 391-6.

[45] Guilbert, S., Cuq, B., and Gontard, N. (1997). Recent innovations in edible and/or biodegradable packaging materials. Food Additives \& Contaminants, 14(6-7), 741-751

[46] Mujica-Paz, H. and Gontard, N. (1997). Oxygen and carbon dioxide permeability of wheat gluten film: effect of relative humidity and temperature. Journal of Agricultural and Food Chemistry, 45(10), 4101-4105.

[47] Irissin-Mangata, J., Bauduin, G., Boutevin, B., and Gontard, N. (2001). New plasticizers for wheat gluten films. European Polymer Journal, 37(8), 1533-1541.

[48] Lai, H. M. and Padua, G. W. (1997). Properties and microstructure of plasticized zein films. Cereal chemistry, 74(6), 771-775.

[49] Park, H. J., Chinnan, M. S., and Shewfelt, R. L. (1994). Edible corn-zein film coatings to extend storage life of tomatoes. Journal of food processing and preservation, 18(4), 317-331.

[50] Zhang, H. and Mittal, G. (2010). Biodegradable protein-based films from plant resources: A review. Environmental progress \& sustainable energy, 29(2), 203-220.

[51] Jane, J., Lim, S., Paetau, I., Spence, K., and Wang, S. (1994). Biodegradable plastics made from agricultural biopolymers. 92-100.

[52] Wu, J. and Muir, A. D. (2008). Comparative structural, emulsifying, and biological properties of 2 major canola proteins, cruciferin and napin. J Food Sci., 2008; 73(3): C210-C216.

[53] Kimber, D. S. and McGregor, D. I. (1995). The spicies and their origin, cultivation and world production. In: Kimber DS, McGregor DI, editors. Brassica oilseeds: production and utilization. Wallingford, England: CAB Intl; 1995. Pp. 1-7.

[54] Tan, S. H., Mailer, R. J., Blanchard, C. L., and Agboola, S. O. (2011). Canola proteins for human consumption: extraction, profile, and functional properties. Journal of Food Science, 76(1), R16-R28.

[55] Bamdad, F., Shin, S. H., Suh, J. W., Nimalaratne, C., and Sunwoo, H. (2017). Anti-Inflammatory and antioxidant properties of casein hydrolysate produced using high hydrostatic pressure combined with proteolytic enzymes. Molecules, $22(4), 609$.

[56] Sosulski, F. W. and Imafidon, G. I. (1990). Amino acid composition and nitrogen-to-protein conversion factors for animal and plant foods. J. Agric. Food Chem., 38: 1351-1356

[57] Kannan, A., Hettiarachchy, N. S., Marshall, M., Raghavan, S., and Kristinsson, H. (2011). Shrimp shell peptide hydrolysates inhibit human cancer cell proliferation. Journal of the Science of Food and Agriculture, 91(10), 1920-1924.

[58] García, M. C., J. M. Orellana, and M. L. Marina. (2016). Novel Applications of Protein By-products in Biomedicine. In Protein Byproducts. In Protein Byproducts (pp. 193-211). Academic Press.

[59] Uthpala, T. G. G., Munasinghe, H. H., Peiris, L. D. C., and Navaratne, S. B. (2021). Evaluation of antimicrobial potential and phytochemicals in Acmella (A. oleracea) flower pod extracts subjected to different drying techniques. Journal of Food Processing and Preservation, e15570.

[60] Huson, M. G. and Elvin, C. M. (2008). 9 Recombinant Resilin-A Protein-Based Elastomer. Current Topics in Elastomers Research, 255.

[61] Kester, J. J. and Fennema, O. (1986). Edible films and coatings: A review. Food Technol., 40: 47-59.

[62] Sahoo, R., Sanket, A. S., Pany, S., Pati, S., and Samal, S. K. (2020). Latest development of biopolymers based on polysaccharides. In Processing and Development of Polysaccharide-Based Biopolymers for Packaging Applications. Pp. 281-299. 